\title{
Improving Quality of Life of Rural Women through Dairying in Bihar
}

\author{
Shweta* and Ashok K. Singh \\ Department of Extension Education, Dr. Rajendra Prasad Central Agricultural University, \\ Pusa (Samastipur), Bihar-848125, India \\ *Corresponding author
}

\section{A B S T R A C T}

\begin{tabular}{|l|}
\hline Key w o r d s \\
Quality of Life; \\
Rural Women in \\
Dairy Enterprise \\
\hline Article Info \\
\hline $\begin{array}{l}\text { Accepted: } \\
\text { 18 May 2019 } \\
\text { Available Online: } \\
\text { 10 June 2019 }\end{array}$ \\
\hline
\end{tabular}

Dairy farming offers great opportunity for enhancing farm income and raising the socioeconomic status and quality of life of rural people. Rural women plays significant role in carrying out the responsibility of dairying through their membership in WDCS. The present study was conducted to ascertain the improvement in their quality of life through participation in dairy enterprise. For the purpose, a total 210 members of WDCS in Barauni dairy was selected by adopting appropriate sampling procedure. The data pertaining to different aspects of quality of life was collected with the help of a scale developed and adopted by Pandey (2005).It may be concluded that dairy enterprise has helped the rural women in reducing the domestic violence and poverty while it brought improvement in their social, recreational, educational and economic well- being and consequently improved their quality of life. The personal variable like; education, type of family and occupation emerged as significant factors in improving the quality of life of rural women.

\section{Introduction}

The animal husbandry and dairy is the main subsidiary income generating activity for the rural people in Bihar. It is an important source of income and employment for millions of landless poor including women. Women's participation in dairy farming is considered as an important activity in reducing the poverty and raising their quality of life, because women accounts for 93 per cent of total employment in dairy production in India (Belurkar et al., 2003). The contribution and subsequent impact on women members of rural family due to dairying is not documented systematically as yet whenever in India about 75 million women as against 15 million men are engaged in dairying (Thakur and Chander, 2006).

Women play a crucial role in dairying and their quality of life is improving but it is still find the place in scientific research endeavour. Therefore, an attempt was made to ascertain the extent of improvement in the quality of life through their active involvement and participation in dairying which is solely managed by them as an enterprise with the collaboration of COMFED, Bihar. 


\section{Materials and Methods}

The COMFED is currently working in 31 district of Bihar, it collects about $7 \%$ of the marketable surplus of milk which comes to 4.77 lakh litres of milk per day. It is the largest organized milk marketing institution which covers around 7892 villages and nearly three lakh farm families. The state of Bihar ranked at ninth position in milk production in the country. There are six milk sheds in the state but the study was carried out in Barauni dairy of Begusarai district of Bihar State because it is the largest milk shed in Bihar. At the second stage of sample selection Bachhwara and Bhagwanpur block of Barauni dairy were identified as the location of study which has the largest number of WDCS (Women Dairy Cooperative Societies). At the third stage of sample selection three WDCS were selected from each block with the help of random sampling procedure. Finally, 35 members from each WDCS comprising total 210 members of WDCS of Barauni dairy were taken as the sample of study. They were administered a scale of quality of life, which was adopted version of original scale used by Pandey (2005). It consists of nine areas pertaining to the individual's quality of life. The areas were social, recreational, personal grooming, domestic violence, material possession, housing, educational, nutritional, health and economics.

\section{Results and Discussion}

The quality of life includes the consequential outcome of various developments which have taken place in their social, recreational activities, personal grooming, and domestic violence, material possession, housing status, educational level, nutritional and health status and economic aspect of family members by virtue of their membership in dairy cooperative societies. An attempt has been made hereto elicit the information from respondents on three point's scale that is increased, similar and decreased. The frequencies and their percentage scores were presented here in Table 1.

From perusal of Table 1, indicated that there was substantial increase in socialization of members of WDCS, particularly an increase in size of social circle (76.19\%), social participation (65.24\%), and self-social recognition (64.29\%) along with the status of family in the society $(51.90 \%)$. Almost none of the respondents reported decrease in these social components. Here, increase in social segment might have improved the quality of life among the members of WDCS. Respondents were further asked for improvement in various items related with their recreational activities but $61.43 \%$ of them opined that there was substantial increase in celebration of festivals.

They reported that it was made possible due to increase in the cash flow from sale of milk to the members of WDCS. The results further pointed out that there was increase in number and quality of clothing but only $17.62 \%$ respondents reported marginal increase in possession of jewellery due to membership of WDCS. Domestic violence is very common phenomena in rural areas but members of WDCS reported sharp decline in their domestic violence (more than 90\%). This may be considered as an important contribution of WDCS in empowering rural women through their participation in dairy enterprise.

Material possession is also one of the important indicators for quality of life. The respondents reported substantial increase in low prestige items $(74.29 \%)$ and least increase in high prestige items (5.24\%). It was mainly due to low level of cash flow and lesser saving of respondents, as majority of them belonged to small and marginal categories of farm households. 
Table.1 Improving quality of life through dairying among the members of WDCS

\begin{tabular}{|c|c|c|c|c|c|c|}
\hline Areas & $\begin{array}{l}\text { Increased } \\
\text { (f) }\end{array}$ & $\%$ & $\begin{array}{l}\text { Similar } \\
\text { (f) }\end{array}$ & $\%$ & $\begin{array}{l}\text { Decreased } \\
\text { (f) }\end{array}$ & $\%$ \\
\hline \multicolumn{7}{|l|}{ Social } \\
\hline $\begin{array}{l}\text { Social recognition of } \\
\text { self }\end{array}$ & 135 & 64.29 & 75 & 35.71 & 0 & 0.00 \\
\hline Social participation & 137 & 65.24 & 73 & 34.76 & 0 & 0.00 \\
\hline Size of social circle & 160 & 76.19 & 50 & 23.81 & 0 & 0.00 \\
\hline $\begin{array}{l}\text { Status of family in } \\
\text { society }\end{array}$ & 109 & 51.90 & 101 & 48.10 & 0 & 0.00 \\
\hline \multicolumn{7}{|l|}{ Recreational } \\
\hline Holidays, outing & 1 & 0.48 & 207 & 98.57 & 2 & 0.95 \\
\hline $\begin{array}{l}\text { Hosting/attending } \\
\text { parties }\end{array}$ & 7 & 3.33 & 201 & 95.71 & 2 & 0.95 \\
\hline Time for hobbies & 0 & 0.00 & 205 & 97.62 & 5 & 2.38 \\
\hline $\begin{array}{l}\text { Celebration of } \\
\text { festivals/ceremonies }\end{array}$ & 129 & 61.43 & 81 & 38.57 & 0 & 0.00 \\
\hline \multicolumn{7}{|l|}{ Personal grooming } \\
\hline Clothing & 135 & 64.29 & 75 & 35.71 & 0 & 0.00 \\
\hline Jewellery & 37 & 17.62 & 173 & 82.38 & 0 & 0.00 \\
\hline \multicolumn{7}{|l|}{ Domestic violence } \\
\hline Abuse & 0 & 0.00 & 14 & 6.67 & 196 & 93.33 \\
\hline Physical torture & 0 & 0.00 & 14 & 6.67 & 196 & 93.33 \\
\hline Mental torture & 0 & 0.00 & 15 & 7.14 & 195 & 92.86 \\
\hline \multicolumn{7}{|l|}{ Material possession } \\
\hline Low prestige items & 156 & 74.29 & 54 & 25.71 & 0 & 0.00 \\
\hline Medium prestige items & 82 & 39.05 & 128 & 60.95 & 0 & 0.00 \\
\hline High Prestige items & 11 & 5.24 & 198 & 94.29 & 0 & 0.00 \\
\hline \multicolumn{7}{|l|}{ Housing } \\
\hline Rent & 0 & 0.00 & 210 & 100.00 & 0 & 0.00 \\
\hline Furnishing & 1 & 0.48 & 209 & 99.52 & 0 & 0.00 \\
\hline Repair/Maintenance & 9 & 4.29 & 201 & 95.71 & 0 & 0.00 \\
\hline Home improvement & 26 & 12.38 & 184 & 87.62 & 0 & 0.00 \\
\hline Construction & 17 & 8.10 & 193 & 91.90 & 0 & 0.00 \\
\hline Interior decoration & 0 & 0.00 & 210 & 100.00 & 0 & 0.00 \\
\hline \multicolumn{7}{|l|}{ Educational } \\
\hline $\begin{array}{l}\text { Better schooling of } \\
\text { children }\end{array}$ & 114 & 54.29 & 96 & 45.71 & 0 & 0.00 \\
\hline
\end{tabular}




\begin{tabular}{|l|c|c|c|c|c|c|}
\hline $\begin{array}{l}\text { Provision of private } \\
\text { tuition/coaching }\end{array}$ & $\mathbf{7 0}$ & $\mathbf{3 3 . 3 3}$ & $\mathbf{1 4 0}$ & $\mathbf{6 6 . 6 7}$ & $\mathbf{0}$ & $\mathbf{0 . 0 0}$ \\
\hline $\begin{array}{l}\text { Enrolment in extra- } \\
\text { curriculum courses like } \\
\text { computers, art classes } \\
\text { etc }\end{array}$ & 19 & 9.05 & 191 & 90.95 & 0 & 0.00 \\
\hline Nutrition and health & & & & & & \\
\hline Expenses on food & 123 & 58.57 & 87 & 41.43 & 0 & 0.00 \\
\hline Quality/variety of food & 64 & 30.48 & 146 & 69.52 & 0 & 0.00 \\
\hline $\begin{array}{l}\text { Expenses on health } \\
\text { care }\end{array}$ & 65 & 30.95 & 145 & 69.05 & 0 & 0.00 \\
\hline $\begin{array}{l}\text { Experience of strain or } \\
\text { fatigue }\end{array}$ & 187 & 89.05 & 23 & 10.95 & 0 & 0.00 \\
\hline Economic & 174 & 82.86 & 32 & 15.24 & 4 & 1.90 \\
\hline Income & 174 & 82.86 & 33 & 15.71 & 3 & 1.43 \\
\hline Expenditure & 75 & 35.71 & 132 & 62.86 & 3 & 1.43 \\
\hline Saving & 46 & 21.90 & 161 & 76.67 & 3 & 1.43 \\
\hline Investment & & & & & & \\
\hline
\end{tabular}

Table.2 Ordered logistic regression between the independent variables and quality of life of WDCS members

\begin{tabular}{|l|c|c|c|}
\hline Explanatory variable & Coefficient & Standard error & Z value \\
\hline Age (years) & 0.0143 & 0.0137 & 1.04 \\
\hline Education (years) & $0.0802^{* *}$ & 0.0346 & 2.32 \\
\hline Type of family (Joint -1, otherwise-0) & $0.5153^{*}$ & 0.2858 & 1.80 \\
\hline $\begin{array}{l}\text { Occupation (Agriculture \& dairy -1, } \\
\text { otherwise-0) }\end{array}$ & $0.7907^{* * *}$ & 0.2901 & 2.73 \\
\hline Land Holding (Marginal -1, otherwise-0) & -0.2349 & 0.3172 & -0.74 \\
\hline $\begin{array}{l}\text { No. of dairy animal (Upto 2 animal -1, } \\
\text { otherwise -0) }\end{array}$ & -0.3712 & 0.3302 & -1.12 \\
\hline No. of observation & 210 & & \\
\hline $\mathbf{R}^{2}$ & 0.4740 & & \\
\hline Log likelihood & -185.8793 & & \\
\hline
\end{tabular}

$* * * * *$ and * indicate 1,5 and $10 \%$ level of significance, respectively.

Housing is one of the important indicators of quality of life. The housing is a central issue in community life. The better maintained housing is symbol of prestige and provides an improved living facility which often helps in improving the quality of life. During the present study, the information was sought mainly for furnishing, repair/maintenance of house, home improvement, construction and interior decoration. Housing required heavy investment, hence improvement in housing emerged as an important item and increase in expenses on this item was reported by only $12.38 \%$ of respondents. Construction and 
repair of house have also been reported by $8.10 \%$ and $4.29 \%$ of respondents respectively. With the help of dairy enterprise about $54.29 \%$ of the respondents opined that they were able to provide better education to their children after joining WDCS. One third of the respondents also reported about the availability of avenues such as private coaching to their children with the help of earning coming from dairy enterprise.

An attempt was also made to find out the impact of WDCS on nutrition and health of members. About $89.05 \%$ reported an increase in strain or fatigue due to membership of WDCS whereas about one third of respondents reported about increase in quality/variety of food and more expenses on health care. The majority of household under study belonged to weaker section of society hence; about $58.57 \%$ of them reported more expenses on food. Hence, it may be concluded that WDCS had helped them in strengthening the food security and improved access to health care facility which were important components of quality of life. Economic status is pre-requisite for quality of life. Quality of life cannot be improved without increase in cash flow in the household. The increase in income and expenditure were reported by $83 \%$ of respondents. However, $35.71 \%$ respondents indicated increase in saving and $21.90 \%$ reported increase in investment also. Increase in expenditure, saving and investment were the indicators for improvement in quality of life of the respondents.

Further, an effort was made to find out the determinants of quality of life related with member of WDCS participated in the study. For the purpose ordered logistic regression model was used to find out the determinants of quality of life among the member. The findings are presented here in Table 2. Index of quality of life was dependent variable in the analysis whereas age, education, type of family, occupation, land holdings and number of dairy animals owned were considered as independent variables which were expected to exert influence on quality of life of WDCS members. The estimated $\mathrm{R}^{2}$ was 0.47 which indicates that the variables included in the analysis explain 45 per cent variation in dependent variable (quality of life of women). The findings suggested that variables like; education, type of family and occupation emerged as significant and positive variables affecting the quality of life of women of WDCS. The highly educated women of joint family with agriculture and dairy as their main occupation were likely to had better quality of life as compared to the low educated and nuclear family members of WDCS. However, the coefficients of ownership of number of dairy animals and land holdings were found non-significant. The variable age had positive relationship with quality of life but was also not found significant during the study.

Thus, dairy enterprise is an important aspect to generate economy activity and selfemployment opportunities for women. It has the propensity to increase the family income and standards of living of the women. Proper functioning of micro enterprises developed capacity as well as empowered women to improve their socio-economic status. In spite of having positive impact, the overall performance of the women entrepreneurs is still to go in long way for further improvement in their quality of life. The governmental and non-governmental organisations should join hands together to take initiatives to increase women's participation in the small business. In this regard there is need to have easy access to institutional credit and marketing to the rural women. They should also be given proper training to develop their skills and knowledge related with business and market 
environment. Based on the findings, it is concluded that dairy enterprise has helped the rural women in reducing their domestic violence and poverty in order to bring the improvement in their social, recreational, housing, educational, material possession, nutritional and health and economic wellbeing which ultimately determine their quality of life to a great extent.

\section{References}

Belurkar, G.M., Wakle, P.K. and Gholve, M.A. 2003. A study on decision making pattern and participation of rural women in animal husbandry and dairying enterprise. Maharashtra Jr. of Ext. Edu. 22 (2): 81-85.

Pandey, R. 2005. Empowerment of women through women dairy cooperative. Unpublished Ph.D. Thesis, CCSHAU, Hisar.

Thakur, D. and Chandar, M. 2006. Gender based differential access to information among livestock owners and its impact on house hold milk production in Kangra district of Himachal Pradesh. Indian Jr. of Dairy Sc. 59 (6): 401-404.

\section{How to cite this article:}

Shweta and Ashok K. Singh. 2019. Improving Quality of Life of Rural Women through Dairying in Bihar. Int.J.Curr.Microbiol.App.Sci. 8(06): 2465-2470.

doi: https://doi.org/10.20546/ijcmas.2019.806.294 